\title{
TERRITÓRIO E MOBILIDADE: ABORDAGENS COM ENFOQUE NAS NECRÓPOLES
}

西
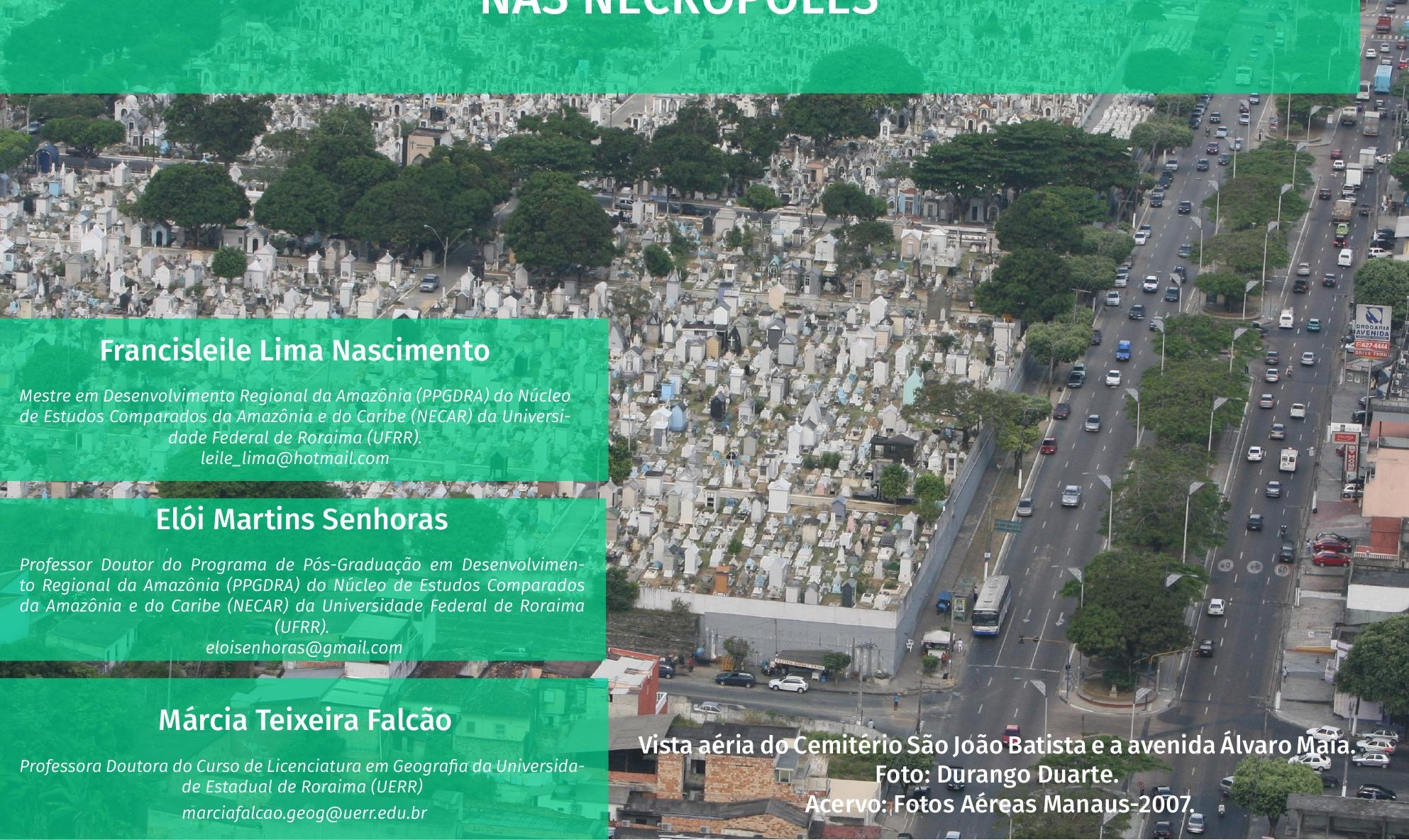

\section{RESUMO}

Dentro do simbolismo com os estudos antropológicos, as "cidades necrópoles" compõe território de construções abstratas como as tradições, os costumes, além de um espaço de memórias históricas, sociais, religiosas e culturais. O surgimento das necrópoles partiu da necessidade de o homem enterrar seus mortos. A preocupação com o lugar adequado para enterrar seus mortos foram surgindo conforme os problemas foram aparecendo por conta das interferências naturais das inumações nos espaços escolhidos para tal atividade. Portanto, o presente artigo em referência tem como objetivo analisar o processo histórico das necrópoles desde os períodos Pré-históricos; na Antiguidade; no Egito, Roma Monárquica, na República, no Império; Idade Média e Contemporânea; em Portugal e finalmente no Brasil, além de conceitos sobre território e mobilidade trazendo uma abordagem com enfoque nas necrópoles. A metodologia está fundamentada em autores que trazem uma reflexão sobre a temática em discussão, com fins de embasar os posicionamentos dos autores sem pretensão de apresentar verdades prontas e acabadas, mas na busca de despertar para a necessidade de se repensar os fatos históricos mais antigos até a sua atualidade, perpassando pelo mundo até chagar ao Brasil a respeito das necrópoles (cemitérios). As práticas funerárias mais antigas e quase esquecidas foram praticadas em algumas poucas civilizações e mais notáveis pelo seu legado, é um território que possui fluxos de mobilidades físicas e abstratas.

Palavras - chave: Civilização. Escala temporal. Territorialidades. Mobilizações. Cemitérios.
ABSTRACT

Within the symbolism with the anthropological studies, the "necropolis cities" comprise territory of abstract constructions like the traditions, the customs, besides a space of historical, social, religious and cultural memories. The appearance of the necropolises came from the need of man to bury his dead. The concern with the proper place to bury their dead were appearing as the problems were appearing because of the natural interferences of the burials in the spaces chosen for such activity. Therefore, the present article in reference has as objective to analyze the historical process of the necropolis from the Prehistoric periods; in ancient times; In Egypt, Monarchical Rome, in the Republic, in the Empire; Middle and Contemporary Age; In Portugal and finally in Brazil, as well as concepts about territory and mobility, bringing an approach with a focus on the necropolises. The methodology is based on authors who bring a reflection on the subject under discussion, in order to base the authors' positions without pretension to present ready and finished truths, but in the search of awakening to the need to rethink the historical facts older until Its actuality, passing through the world until it reaches Brazil about the necropolises (cemeteries). The oldest and almost forgotten funerary practices were practiced in a few civilizations and most notable for their legacy, is a territory that has flows of physical and abstract mobility.

Keywords: Civilization. Time scale. Territorialities. Mobilizations. Cemetery. 


\section{INTRODUÇÃO}

Os estudos sobre cemitério estão dentro do contexto dos temas tabus, por esse motivo o mundo acadêmico e científico não pode e nem deve evitar pesquisa relacionadas a temática, tendo em vista a necessidade de tornar conhecida as dimensões que permeiam - local nos aspectos sociais, culturais, religiosos, políticos, entre outros, bem como os aspectos ambientais e de saúde pública quando se considera que o cadáver humano pode ser causa de alterações ambientais e pôr em risco a saúde dos vivos (PINHEIRO, 2018).

Sendo os cemitérios repositórios de cadáveres, laboratórios de decomposição de matéria orgânica, apresentam riscos que devem ser controlados por meio de projetos adequados de implantação e operação. As necrópoles tardam a aparecer nas listas das fontes tradicionais de contaminação ambiental, apesar da frequente contaminação da água subterrânea por cemitérios mal implantados e gerenciados (PACHECO, 2012).

O realismo da vida moderna, com suas muitas exigências, induz a sociedade ocidental a encarar de outro modo o fenômeno natural da morte e a prática concreta do sepultamento (enterrar; enterro), do destinoúltimo dos restos mortais das pessoas queridas. Além do aspecto biológico ou do necrológico, há considerações de várias ordens: cultural, religiosa, sanitária, urbanística, socioeconômico, fundiária e, por conseguinte, ambiental (PACHECO, 2012).

Os cemitérios de caráter tradicional (público e privado), os convencionais e os jardins, todos colocam problemas para o meio ambiente, problemas às vezes confusos, inclusive sob o ponto de vista jurídico, que vêm se complexificando com a própria vida de hoje (KEMERICH, 2014).

Além disso, tem-se o planejamento urbano ao qual enfrenta escassez crescente de área disponivel para inumações, especificamente nas grandes cidades. As áreas porventura existentes revelam-se frágeis para contornar graves problemas sanitários relacionados com a poluição do solo e de lençóis freáticos subjacentes ou próximos (PACHECO, 2012).

Os cemitérios verticais (prédios), bem como os horizontais (de forma tradicional) instalados, não escapam a problemas semelhantes, embora os cemitérios verticais apresentem problemas em menor intensidade. Os crematórios multiplicam-se com obstáculos de ordem cultural ou religiosa, ademais da própria legislação para construção e instalação do mesmo, e apresentar diversas particularidades ao qual dificulta esse processo (PINHEIRO, 2018).

Esse panorama demostra que o destino último planetários de milhões de pessoas que, a cada semana, dá baixa nos contingentes da família humana, passa a ser, seguramente, uma problemática ambiental nas mais vertentes, mas especificamente em saúde pública e do saneamento, além de socioeconômica, e até certo ponto, demográfica (PACHECO, 2012).

0 presente artigo em referência tem como objetivo analisar o processo histórico das necrópoles desde os períodos Pré-históricos; na Antiguidade; no Egito, Roma Monárquica, na República, no Império; Idade Média e Contemporânea; em Portugal e finalmente no Brasil, contextualizando-o amparado nas teorias do território e mobilidade trazendo uma abordagem com enfoque nas necrópoles. A metodologia está fundamentada em autores que trazem uma reflexão sobre a temática em discussão, com fins de embasar os posicionamentos dos autores sem pretensão de apresentar verdades prontas e acabadas, mas na busca de despertar para a necessidade de se repensar os fatos históricos mais antigos até a sua atualidade, perpassando pelo mundo até chagar ao Brasil a respeito das necrópoles (cemitérios). As práticas funerárias mais antigas e quase esquecidas foram praticadas em algumas poucas civilizações e mais notáveis pelo seu legado. 
Esta temática ainda é pouca explorada, portanto são escassos autores que abordem a partir de um olhar geográfico. Há uma necessidade de se produzir mais pesquisas e realmente ter a percepção de que o cemitério é um empreendimento que deve ter atenção mais pontual do poder público, que precisa de estudos, de um adequado planejamento para ser construído e mantê-lo ativo.

\section{DISCUSSÃO}

\section{Necrópoles: processo histórico e terminologia}

A palavra cemitério, do grego koimetérion, "dormitório", pelo latim Coemeteriu, significava o lugar onde se dorme quarto, dormitório. Esse significado é explicado pela mitologia grega, segundo a qual dormir (perder o conhecimento ou a consciência) é algo decidido por Hipno, deus grego do sono, o qual não tem o poder de fazer despertar. Hipno, segundo os gregos, era irmão gêmeo de Thanatos, o deus da morte (RANGONI, 2014).

A palavra cemitério, durante muito tempo, pertenceu à linguagem erudita dos clérigos (Sujeito que faz parte da classe eclesiástica clero), sendo os termos "galeria" e "carneiro" os mais antigos para designar o lugar da inumação (sepultamento ou enterramento ou a colocação de cadáver em sepultura, jazido ou local de consunção aeróbia) de cadáveres (PACHECO, 2012).

Dicionários da Língua Portuguesa dão à palavra cemitério outros significados afins: terreno descoberto em que se enterram ou guardam defuntos; luar onde a morte faz muitas vítimas; luar onde existem muitos objetos deteriorados, destruídos; região insalubre, epidêmica e onde se morre muito (RANGONI, 2014).

O termo cemitério teve uma evolução semântica ao longo do tempo, impondo-se definitivamente na língua francesa desde o século XVI. Em inglês, o emprego da palavra cemetery, na linguagem corrente, parece mais tardio. Churchyard ou raveyard só foram substituídas por cemetery, no uso corrente, no século XIX e para designar, por oposição, outra forma de cemitério, o rural cemetery. $\mathrm{Na}$ Terminologia Hebraica o cemitério é designado por termos bastante surpreendentes: Beth Olam (casa da eternidade), Beth há hayim (casa da vida) e no rito alsaciano Gut-Ozt (o bom lugar) (PACHECO, 2012).

O cemitério além de ser um lugar onde os mortos são enterrados, também são fontes históricas, podem conter objetos da memória familiar. Também atestam ideologias políticas e indicam a divisão de classes. "Quando os antigos se evidenciaram como forma de patrimônio cultural, sendo possível, e que por meio de suas esculturas, túmulos, mausoléus, propuseram evidenciar múltiplos aspectos, desde o movimento artístico até a religiosidade de uma época" (LEON LUCAS, 2006, p. 09).

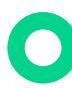

A morte que não poupa nenhum ser vive, atinge também as obras dos homens. E necessário saber reconhecer e discriminar nos testemunhos do passado aquelas que ainda estão bem vivas. Nem tudo que é passado tem, por definição, direito à perenidade (CURY, 2000, p. 52).

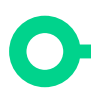

Conforme Koury (2011) em muitas culturas do Oriente, o nascimento significa o momento de dor e sofrimento, já a morte é vista como se a pessoa fosse reviver; diferentemente da cultura ocidental, na qual a morte se afigura com mais intensidade de sentimento de perda, de falta e do fim. "Por este motivo e por conceber que algo como o espírito ainda poderá continuar existindo, constroem-se monumentos tumulares para manter viva a memória do defunto" (LEON LUCAS, 2006, p. 10). 
Foram necessários vários séculos para que o homem viesse a pensar no animismo e que a palavra espírito se concretizasse no termo alma. E uma consequência natural do culto aos mortos seria oferecer a eles, para sua vida eterna, tudo que necessitariam, já que onde viveriam - na tumba - não encontrariam meios de sobreviver. Essa prática de oferendas mortuárias, realizadas quando da sepultação do corpo do morto, perdura até hoje sob a forma de deposição de flores e outras dádivas nas sepulturas. Todavia, este costume persistiu durante muitos séculos no Egito Antigo, sob a forma de esquifes de ouro, joias, adornos, e escravos sepultados vivos junto ao senhor. No Egito antigo, a alma era imortal e de natureza divina, pois mesmo depois de separada do corpo continuava a viver, viajando para a eternidade (NEGRAES, 1982, p. 10).

Foi no Egito antigo que a produção de arte tumular teve seu maior destaque com uma grande imponência religiosa, inclusive a arte era quase toda direcionada para adornar a última morada (COSTA, 2015).“E foi com a civilização grega que surgiram as primeiras lápides de pedra, como forma de identificar os túmulos" (LEON LUCAS, 2006).

Os cemitérios, como hoje são conhecidos, surgiram da necessidade de "melhorar a qualidade de vida nos centros urbanos". Foi a partir do século XVIII que começaram a se distanciar os mortos dos vivos, evitando, assim, doenças como cólera e peste bubônica. Foi na chamada "belle époque" período iniciado por volta de 1880 e que se prolongou até 1914 que a arte europeia se revigorou. "Nos cemitérios mais antigos, é comum encontrarem-se trabalhos de artistas famosos, abrigando os restos de anônimos abastados. Em alguns casos, os mausoléus são verdadeiras obras de valor estético, alvos de visita e turismo" (LEON LUCAS, 2006, p. 11-12).

Nossos "Campos Santos" não representam apenas a última morada para nossos entes queridos. São expressões sociológicas de etnias, de classes sociais, de culturas religiosas, de filosofias, de simbolismos, de es- tilos arquitetônicos e em alguns túmulos, se vê expresso algo comum a todos nós: a vaidade humana, perpetuada após a morte (TELLES, 1977, p. 81).

\section{(O) \\ O cemitério passou a existir por} vários motivos para que assim, se tornasse obrigatório realizar sepultamento de mortos em áreas específicas para isso, as quais são conhecidas como cemitérios. No que diz respeito à prática funerária mais utilizada, tem sido o enterro em sepulturas, onde o caixão é assentado em contato direto com o solo (PINHEIRO, 2018).

A palavra cemitério é de origem grega "KOUMETERIAN" a qual tem o significado "onde eu durmo", porém com o advento do Cristianismo, esse termo assumiu o sentido de local destinado ao repouso final pósmorte, com significado apenas para lugares onde acontece o enterramento dos cadáveres (cadáver - carne dada aos vermes) (PACHECO, 2012).

No Brasil, existem dois tipos de cemitérios: os horizontais (localizados em áreas descobertas, compreendendo os cemitérios tracionais e os do tipo parque ou jardim) e os verticais (edificios de um ou mais pavimentos dotados de lóculos ou câmaras para sepultamentos) (RANGONI, 2014).

Os cemitérios horizontais, em especial os tradicionais (onde os sepultamentos são feitos, comumente, em cova rasa), mobilizam as atenções dos estudiosos da contaminação ambiental, pois nele as inumações são feitas diretamente no solo, na cova, e podem pôr em risco a qualidade da água subterrânea quando implantados de forma inadequada, sem atender às normas de execução (KOURY, 2011).

Enquanto os cemitérios tradicionais são públicos, no sentido de pertencer ao poder público, os do tipo parque ou jardim e os verticais, em geral, são privados, sendo que neste último caso, a administração pública exerce o poder de polícia. Nenhuma 
comunidade pode viver em cemitérios. isso, uma escala temporal foi elaborada São equipamentos sociais fundamentais com intuito de representar o surgimento das para a organização da gestão do lugar e mais "formas cemiteriais" existente desde os para os harmoniosos desenvolvimentos do períodos Pré-históricos; na Antiguidade; no aglomerado urbano (PACHECO, 2012).

A partir disso, várias práticas funerárias existiram ao longo dos séculos em diferentes situações entre os povos e as cidades. Com

Egito, Roma Monárquica, na República, no Império; Idade Média e Contemporânea; em Portugal e finalmente no Brasil (MARTINS, 2015).

\begin{tabular}{|c|c|c|c|c|c|c|}
\hline Período/eras & $\begin{array}{c}\text { Civilização/ } \\
\text { Povos }\end{array}$ & $\begin{array}{c}\begin{array}{c}\text { Séculos/ } \\
\text { Anos }\end{array} \\
\end{array}$ & Observação & $\begin{array}{c}\text { Surgimento do Cemi- } \\
\text { tério }\end{array}$ & $\begin{array}{l}\text { Crenças/Simbo- } \\
\text { lismo/ Religião }\end{array}$ & $\begin{array}{c}\text { Modelo de estrutura do } \\
\text { cemitério }\end{array}$ \\
\hline $\begin{array}{l}\text { PALEOLITICO } \\
\text { INFERIOR E } \\
\text { MÉDIO }\end{array}$ & Homem & $\begin{array}{l}1 \text { milhão } \\
\text { a } 35 \mathrm{mim} \\
\text { anos a.C. }\end{array}$ & & $\begin{array}{l}\text { Munido de apetrechos } \\
\text { de utensílios para ca- } \\
\text { var o solo, tiveram du- } \\
\text { rante muito tempo de } \\
\text { tratar os seus mortos } \\
\text { de maneira discreta, } \\
\text { antes de pensar em se- } \\
\text { pultá-los. } \\
\text { Nessas circunstâncias } \\
\text { os cadáveres eram } \\
\text { lançados nos corpos } \\
\text { de água ou cobertos } \\
\text { por pedras para serem } \\
\text { protegidos dos animais } \\
\text { carnívoros. }\end{array}$ & & \\
\hline $\begin{array}{l}\text { PALEOLÍTICO } \\
\text { MÉDIO }\end{array}$ & $\begin{array}{l}\text { Homem de } \\
\text { Neandertal } \\
\text { (povoado de } \\
\text { Neandertal, } \\
\text { perto de Dus- } \\
\text { seldorf, na } \\
\text { Alemanha). }\end{array}$ & 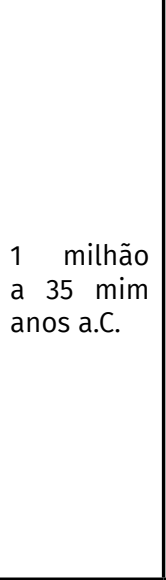 & & $\begin{array}{l}\text { Povo primitivo, progna- } \\
\text { ta, munido de arcadas } \\
\text { supraciliares enormes, } \\
\text { que terá aparecido no } \\
\text { Paleolítico Médio, foi } \\
\text { quem iniciou a prática } \\
\text { da inumação ao enter- } \\
\text { rar os cadáveres nas } \\
\text { fossas, circundados } \\
\text { com pedaços de carne } \\
\text { a fim de que pudessem } \\
\text { alimentar-se na sua } \\
\text { longa viagem. } \\
\text { O morto era colocado } \\
\text { em posição fetal, como } \\
\text { no momento do nasci- } \\
\text { mento (MORIN, 1970). }\end{array}$ & $\begin{array}{l}\text { Essa posição su- } \\
\text { gere uma crença } \\
\text { no seu nascimen- } \\
\text { to (MORIN, 1970). } \\
\text { A sepultura nean- } \\
\text { dertaleses teste- } \\
\text { munha não só a } \\
\text { erupção da morte } \\
\text { na vida huma- } \\
\text { na, mas também } \\
\text { modificações an- } \\
\text { tropológicas que } \\
\text { permitem e provo- } \\
\text { caram essa irrup- } \\
\text { ção (MORIN, 1970). }\end{array}$ & $\begin{array}{l}\text { Os túmulos dos neander- } \\
\text { taleses são os mais anti- } \\
\text { gos, por indicarem algo } \\
\text { diferente de um simples } \\
\text { sepultamento (enterrar; } \\
\text { enterro) para proteger os } \\
\text { vivos da decomposição } \\
\text { (MORIN, 1970). }\end{array}$ \\
\hline $\begin{array}{l}\text { PALEOLÍTICO } \\
\text { SUPERIOR. } \\
\text { (PALEOZÓI- } \\
\text { CO) }\end{array}$ & $\begin{array}{l}\text { Cro-Magnon } \\
\text { (homens que } \\
\text { habitavam o } \\
\text { sul da Fran- } \\
\text { ça). } \\
\text {-Europa Oci- } \\
\text { dental. }\end{array}$ & $\begin{array}{l}35 \text { mil anos } \\
\text { a.C. }\end{array}$ & $\begin{array}{l}\text { Descoberta do } \\
\text { apogeu do talhe } \\
\text { da pedra; aparição } \\
\text { de utensílios ob- } \\
\text { tidos a partir dos } \\
\text { ossos de animais; } \\
\text { invenção da agu- } \\
\text { lha; pintura e da } \\
\text { gravura. }\end{array}$ & $\begin{array}{l}\text { Dos achados sepul- } \\
\text { crais deduz-se que os } \\
\text { mortos eram enterra- } \\
\text { dos tanto dentro das } \\
\text { cavernas, como fora } \\
\text { delas, sem sepulturas } \\
\text { individuais e coletivas. }\end{array}$ & & $\begin{array}{l}\text { Em outros casos, eram se- } \\
\text { pultados em fossas cujo } \\
\text { solo era coberto com pó } \\
\text { de ocre triturado. Com } \\
\text { frequência, os pesa e a } \\
\text { cabeça era protegida por } \\
\text { lousas de pedra. Nos se- } \\
\text { pultamentos (enterrar; } \\
\text { enterro), eram usadas di- } \\
\text { versas posições, ficando } \\
\text { os cadáveres deitados de } \\
\text { costas, de lado ou para } \\
\text { cima, acocorados e encos- } \\
\text { tados em pedras ou meti- } \\
\text { dos dentro de recipientes, } \\
\text { embalsamados ou não. }\end{array}$ \\
\hline
\end{tabular}




\begin{tabular}{|c|c|c|c|c|c|c|}
\hline MESOLÍTICO & $\begin{array}{l}\text { Os habitan- } \\
\text { tes da Europa } \\
\text { viviam na de- } \\
\text { pendência de } \\
\text { uma natureza } \\
\text { selvagem. }\end{array}$ & $\begin{array}{l}10 \text { mil a } 5,5 \\
\text { mil a.C. }\end{array}$ & $\begin{array}{l}\text { Surgiu nesse pe- } \\
\text { ríodo intermediá- } \\
\text { rio a era neolítica } \\
\text { (último período da } \\
\text { idade da pedra). }\end{array}$ & & & \\
\hline MESOLÍTICO & Homem & $\begin{array}{lr}100 & \text { mil } \\
\text { anos, } & \text { a } \\
\text { partir } & \text { dos } \\
10 & \text { mil } \\
\text { a.C. }\end{array}$ & & $\begin{array}{l}\text { Surgiram os primeiros } \\
\text { cemitérios. }\end{array}$ & $\begin{array}{l}\text { Nessa época, tam- } \\
\text { bém se praticou o } \\
\text { culto dos crânios } \\
\text { que vinha do Pale- } \\
\text { olítico. }\end{array}$ & $\begin{array}{l}\text { As sepulturas são agrupa- } \\
\text { das em túmulos individu- } \\
\text { ais e coletivos. }\end{array}$ \\
\hline MESOLÍTICO & Austrália. & \begin{tabular}{|ll}
30 & $\mathrm{mil}$ \\
anos. &
\end{tabular} & $\begin{array}{l}\text { Surgimento da } \\
\text { cremação. }\end{array}$ & & $\begin{array}{l}\text { Consiste na des- } \\
\text { truição das partes } \\
\text { moles do corpo, } \\
\text { sendo as cinzas, } \\
\text { posteriormente } \\
\text { recolhidas para } \\
\text { disposição defini- } \\
\text { tiva. }\end{array}$ & \\
\hline NEOLÍTICO & Homem & $\begin{array}{l}5 \text { mil a } 2 \\
\text { mil a.C. }\end{array}$ & $\begin{array}{l}\text { O homem pré-his- } \\
\text { tórico deixa a vida } \\
\text { nômade e torna-se } \\
\text { sedentário. } \\
\text { Passa a ter habi- } \\
\text { tação fixa, passa } \\
\text { a utilizar a pedra } \\
\text { polida, a cultivar a } \\
\text { terra, a domesticar } \\
\text { os animais, a criar } \\
\text { a primeira indús- } \\
\text { tria têxtil, a usar a } \\
\text { cerâmica e a pros- } \\
\text { pectar os metais. }\end{array}$ & & & \\
\hline \multicolumn{7}{|c|}{$\begin{array}{l}\text { - Entre os seres vivos, o homem é o único que dá à morte e aos mortos uma atenção especial, consequência do uso da linguagem, geradora } \\
\text { de comunicação e cultura. } \\
\text { - Para os arqueólogos, é sobre a forma de sepulturas que se afirmar essa particularidade da espécie humana. } \\
\text { - Na Europa a inumação (enterramento, enterro, sepultamento) sistemática de corpos parece remontar a } 100 \text { mil anos antes da nossa } \\
\text { época. }\end{array}$} \\
\hline NEOLÍTICO & Homem & $\begin{array}{l}4 \text { mil ou } 5 \\
\text { mil a } 2 \text { mil } \\
\text { anos a.C. }\end{array}$ & & $\begin{array}{l}\text { Há um desenvolvimen- } \\
\text { to muito acentuado do } \\
\text { culto aos mortos pela } \\
\text { prática generalizada } \\
\text { da inumação (enterra- } \\
\text { mento, enterro, sepul- } \\
\text { tamento). }\end{array}$ & $\begin{array}{l} \\
\text { Prática do cortejo } \\
\text { e de enterrar jun- } \\
\text { to de cadáveres os } \\
\text { objetos e o mo- } \\
\text { biliário que mais } \\
\text { queridos lhes fo- } \\
\text { ram em vida. }\end{array}$ & $\begin{array}{l}\text { São numerosos os enter- } \\
\text { ramentos isolados ou em } \\
\text { série, em campo raso, nos } \\
\text { quais os cadáveres eram } \\
\text { inumados já em posição } \\
\text { estendida. } \\
\text { Para proteção dos res- } \\
\text { tos mortais, levantava-se } \\
\text { muitas vezes uma peque- } \\
\text { na construção de pedra, } \\
\text { geralmente uma cista } \\
\text { (urna/cofre) retangular, } \\
\text { formada com pequenas } \\
\text { lousas e coberta com pla- } \\
\text { cas de pedra. A prática da } \\
\text { cremação era utilizada, } \\
\text { mas não correntemente } \\
\text { como a inumação (enter- } \\
\text { ramento, enterro, sepulta- } \\
\text { mento). }\end{array}$ \\
\hline \multicolumn{7}{|c|}{$\begin{array}{l}\text { - Na antiguidade oriental e na clássica continuaram a ser praticadas inumação (enterramento, enterro, sepultamento) e a cremação (inci- } \\
\text { neração) e de cadáveres. } \\
\text { - Os ritos fúnebres seguiram os mesmos hábitos e costumes, com algumas diferenças, segundo sua evolução em cada lugar. } \\
\text { - A arte de embalsamar foi desenvolvida por algumas civilizações, com destaque para a egípcia, a que mais venerou os seus mortos. }\end{array}$} \\
\hline
\end{tabular}




\begin{tabular}{|c|c|c|c|c|c|c|}
\hline NEOLÍTICO & $\begin{array}{l}\text { Homem Egíp- } \\
\text { cio (Antigo } \\
\text { Egito). }\end{array}$ & $\begin{array}{l}5 \text { mil anos } \\
\text { a.C. }\end{array}$ & $\begin{array}{l}\text { Surge no baixo } \\
\text { Egito o grande po- } \\
\text { voado de Merinde } \\
\text { Beni Salame, cons- } \\
\text { tituído por choças } \\
\text { de traçado circular } \\
\text { ou oval, constru- } \\
\text { idas com barro, } \\
\text { juncos e canais, } \\
\text { surgiu às primeiras } \\
\text { necrópoles. }\end{array}$ & $\begin{array}{l}\text { Os cadáveres eram inu- } \\
\text { mados (em atitude de } \\
\text { repouso) em cova sim- } \\
\text { ples, sobre uma esteira } \\
\text { ou pele de animal, no } \\
\text { interior do povoado. }\end{array}$ & & $\begin{array}{l}\text { Enterramento arcaico: } \\
\text { simples covas abertas na } \\
\text { terra para todas as cama- } \\
\text { das sociais. Estas sepul- } \\
\text { turas constituem as amis } \\
\text { antigas necrópoles egíp- } \\
\text { cias. } \\
\text { Segundo momento: as se- } \\
\text { pulturas foram cobertas e } \\
\text { protegidas por uma cons- } \\
\text { trução de tijolos, gesso e } \\
\text { outros materiais. }\end{array}$ \\
\hline NEOLÍTICO & $\begin{array}{l}\text { Homem Egíp- } \\
\text { cio (Antigo } \\
\text { Egito - Impé- } \\
\text { rio Antigo). }\end{array}$ & $\begin{array}{l}\text { 2. } 630 \mathrm{mil} \\
\text { anos a.C. }\end{array}$ & $\begin{array}{l}\text { O arquiteto Imho- } \\
\text { tep construiu para } \\
\text { o rei Djoser, a pirâ- } \\
\text { mide em degraus, } \\
\text { a primeira pirâmi- } \\
\text { de em escala do } \\
\text { eito, marguem es- } \\
\text { querda do rio Nilo. } \\
\text { As três grandes } \\
\text { pirâmides de Gizé, } \\
\text { construídas na na } \\
\text { quarta dinastia } \\
\text { (Império Antigo), } \\
\text { feitas de calcário } \\
\text { duro, situadas pró- } \\
\text { ximo do Cairo. }\end{array}$ & $\begin{array}{l}\text { Essa pirâmide é uma } \\
\text { grande atração de Saq- } \\
\text { qara, fazendo parte de } \\
\text { um grande complexo } \\
\text { funerário que se esten- } \\
\text { dia por } 70 \text { quilômetros } \\
\text { ao longo do rio Nilo. }\end{array}$ & $\begin{array}{l}\text { Nas construções } \\
\text { de grande por- } \\
\text { te como as pirâ- } \\
\text { mides de Gizé, } \\
\text { os faraós eram } \\
\text { sepultados com } \\
\text { os corpos mumi- } \\
\text { ficados (método } \\
\text { de preservação } \\
\text { de corpos) artifi- } \\
\text { cialmente, isto é, } \\
\text { em balsama ós } \\
\text { (técnica de pre- } \\
\text { servação de cadá- } \\
\text { veres para preve- } \\
\text { nir a putrefacção), } \\
\text { prática fundada } \\
\text { na sobrevivência } \\
\text { da alma na eterni- } \\
\text { dade. }\end{array}$ & $\begin{array}{l}\text { É uma construção de cal- } \\
\text { cário, com seis amplos } \\
\text { degraus e } 61 \text { metros de } \\
\text { altura, os quais são um } \\
\text { empilhamento de masta- } \\
\text { bas (banco de pedra) ele- } \\
\text { vando-se sobre incontá- } \\
\text { veis túmulos ocultos pela } \\
\text { areia. } \\
\text { Além das pirâmides, os } \\
\text { sarcófagos (urna funerá- } \\
\text { ria, geralmente de pedra, } \\
\text { colocada sobre o solo ou } \\
\text { enterrada) foram estru- } \\
\text { turas de sepultamentos } \\
\text { (enterrar; enterro), conhe- } \\
\text { cida como a "cidade dos } \\
\text { mortos", foi surgindo ao } \\
\text { entorno das pirâmides. }\end{array}$ \\
\hline \multicolumn{7}{|c|}{$\begin{array}{l}\text { - Um dos maiores cemitérios da antiguidade, com mais de } 5 \text { quilômetros quadrados, foi encontrado em Bahariya, um oásis situado a } 370 \\
\text { quilômetros a sudoeste da cidade do Cairo. }\end{array}$} \\
\hline NEOLÍTICO & $\begin{array}{l}\text { Roma Monár- } \\
\text { quica, Repu- } \\
\text { blicana e Im- } \\
\text { perial. }\end{array}$ & $\begin{array}{l}\text { Século IV } \\
\text { a.C. }\end{array}$ & $\begin{array}{l}\text { Na Monarquia Ro- } \\
\text { mana, a realeza e } \\
\text { outras persona- } \\
\text { gens ilustres eram } \\
\text { inumadas no Cam- } \\
\text { po de Marte em } \\
\text { Roma, já o povo } \\
\text { era cremado. } \\
\text { Na Roma Repu- } \\
\text { blicana, a prática } \\
\text { de cremação já } \\
\text { era exclusiva dos } \\
\text { senhores nobres, } \\
\text { ao quais as cinzas } \\
\text { eram colocadas } \\
\text { nas urnas em salas } \\
\text { subterrâneas, já a } \\
\text { plebe erasepulta } \\
\text { em covas rasa, va- } \\
\text { las abertas ou po- } \\
\text { ços funerários ao } \\
\text { entorno da cidade. }\end{array}$ & $\begin{array}{l}\text { Com a difusão do } \\
\text { cristianismo, que in- } \\
\text { terditou a cremação } \\
\text { predominante durante } \\
\text { os primeiros séculos } \\
\text { do império Romano, a } \\
\text { inumação teve uma es- } \\
\text { calada, tornando-se- a } \\
\text { forma de enterramento } \\
\text { mais comum. } \\
\text { Os cristãos passam a } \\
\text { sepultar seus mortos } \\
\text { nas catacumbas (pa- } \\
\text { lavra de origem grega } \\
\text { que significa cavida- } \\
\text { de, um vale aberto) de } \\
\text { Roma, antigos cemité- } \\
\text { rios subterrâneos, com } \\
\text { cavidades ou lóculos } \\
\text { (destinado a abrigar } \\
\text { um cadáver) funerários } \\
\text { nas paredes, escava- } \\
\text { dos nos tufos vulcâ- } \\
\text { nicos do subsolo da } \\
\text { cidade. }\end{array}$ & $\begin{array}{l}\text { Por exigência da } \\
\text { lei Romana, todos } \\
\text { os corpos encer- } \\
\text { rados em urnas } \\
\text { ou sarcófagos, no } \\
\text { solo, deviam ser } \\
\text { sepultados fora } \\
\text { das muralhas, } \\
\text { para que o templo } \\
\text { e as festas religio- } \\
\text { sas não fossem } \\
\text { manchados pela } \\
\text { morte. }\end{array}$ & $\begin{array}{l}\text { As covas eram construídas } \\
\text { ao entorno da muralha } \\
\text { Serviana, uma barreira } \\
\text { defensiva à volta da cida- } \\
\text { de de Roma, com } 11 \text { quilô- } \\
\text { metros de comprimento. }\end{array}$ \\
\hline
\end{tabular}




\begin{tabular}{|c|c|c|c|c|c|}
\hline NEOLÍTICO & $\begin{array}{l}\text { Idade Média } \\
\text { à Contempo- } \\
\text { rânea }\end{array}$ & $\begin{array}{l}\text { Século V e } \\
\text { meados do } \\
\text { século XV. }\end{array}$ & $\begin{array}{l}\text { A partir do século } \\
\text { VII ocorreu uma } \\
\text { mudança que, le- } \\
\text { vou ao abando- } \\
\text { no de cemitérios } \\
\text { campais, os quais } \\
\text { foram cobertos } \\
\text { pela vegetação, } \\
\text { esquecidos ou } \\
\text { usados somen- } \\
\text { te em tempos de } \\
\text { pestes. } \\
\text { É nessa época que } \\
\text { os mortos deixam } \\
\text { o subúrbio e pas- } \\
\text { sam a ser sepulta- } \\
\text { dos "intramuros", } \\
\text { à volta da igreja ou } \\
\text { no interior desta. } \\
\text { Os mortos retor- } \\
\text { nam ao convivio } \\
\text { com dos vivos } \\
\text { com a penetração } \\
\text { de cemitérios no } \\
\text { ambiente urbano, } \\
\text { ao lado das habi- } \\
\text { tações da comuni- } \\
\text { dade. }\end{array}$ & $\begin{array}{l}\text { Nas topografias urba- } \\
\text { nas, os cemitérios já } \\
\text { não são visíveis ou já } \\
\text { não tem identidade, } \\
\text { confunde-se com as } \\
\text { dependências da igreja } \\
\text { e os espaços públicos. } \\
\text { A responsabilidade dos } \\
\text { enterros manteve-se a } \\
\text { cargo da igreja até o } \\
\text { século XVIII, na Euro- } \\
\text { pa ocidental, quando } \\
\text { surgiu o cemitério mo- } \\
\text { derno, que tem a sua } \\
\text { origem no pensamento } \\
\text { do lluminismo. }\end{array}$ & $\begin{array}{l}\text { Cemitérios paroquiais, ou } \\
\text { seja, dentro das próprias } \\
\text { igrejas eram construídos } \\
\text { para sepultamentos. } \\
\text { Os corpos eram enter- } \\
\text { rados no subsolo (piso } \\
\text { interior da igreja) ou em } \\
\text { sepulturas construidas na } \\
\text { superficie. }\end{array}$ \\
\hline \multicolumn{6}{|c|}{$\begin{array}{l}\text { - Nas décadas de } 1770 \text { e } 1780 \text {, soberanos esclarecidos nos paises da Europa proclamaram éditos (anúncio de uma lei) que baniam os } \\
\text { enterros intramuros, encorajando a construção de locais de inumação na periferia das áreas urbanas. } \\
\text { - } 0 \text { cemitério dos Santos Inocentes, o maior de Paris, situado no centro da cidade, que servia mais de } 20 \text { paróquias e recebia pobres e } \\
\text { ricos havia oito séculos, foi desativado em dezembro de } 1780 \text {, antes da revolução francesa. } \\
\text { - Essas necrópoles, que serviram de modelo aos novos cemitérios urbanos da Europa, com o tempo, foram absorvidas pela expansão } \\
\text { urbana da cidade de paris. } \\
\text { - Atualmente, estão localizadas intramuros e são muito visitadas por milhares de turistas, não só por causa das personalidades ali sepul- } \\
\text { tados, mas também pelas magnificas esculturas funerárias. }\end{array}$} \\
\hline
\end{tabular}




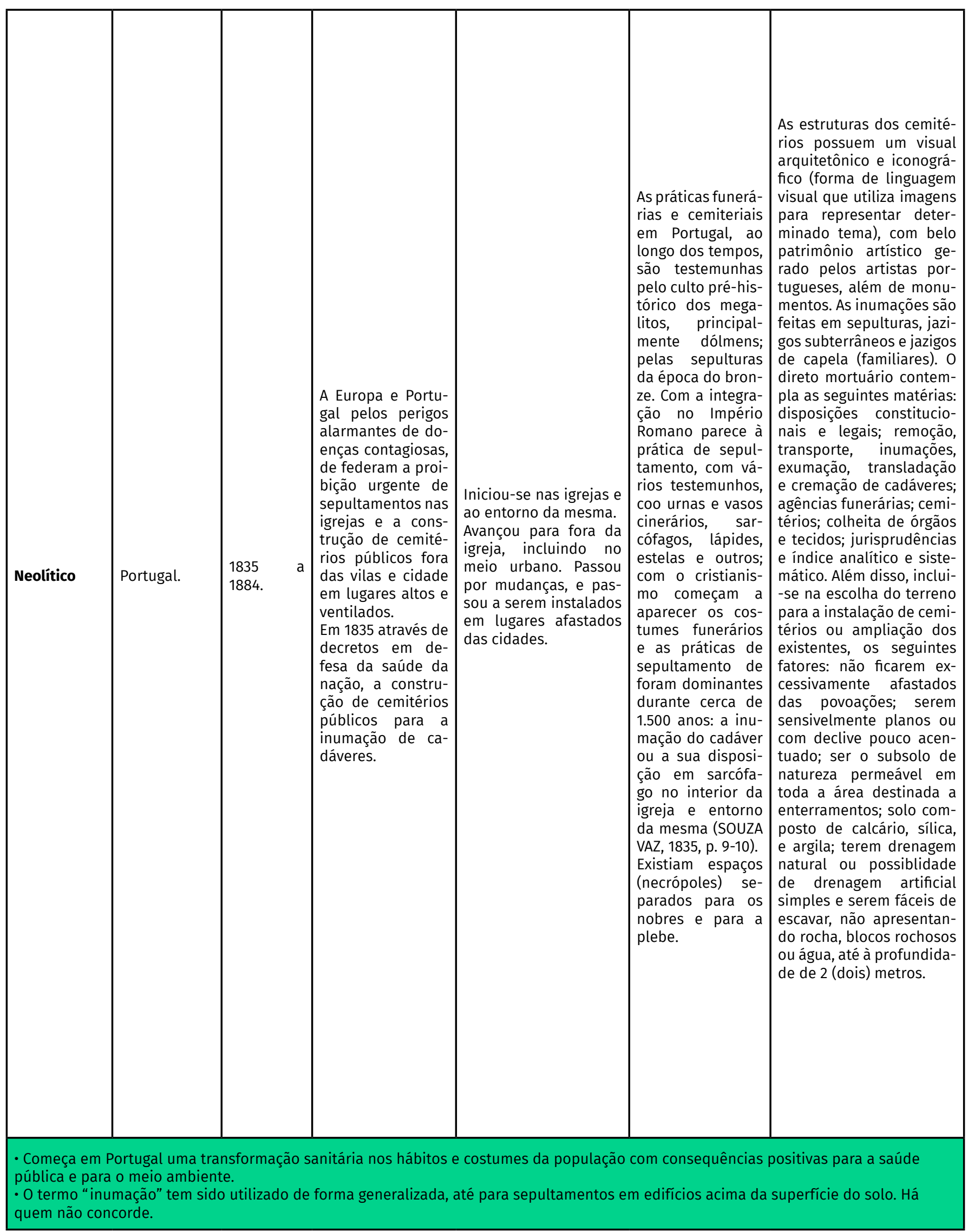




\begin{tabular}{|c|c|c|c|c|c|c|}
\hline Neolítico & Brasil. & \begin{tabular}{|l|} 
Século \\
XVIII. \\
Ano 1798. \\
Século XIX.
\end{tabular} & $\begin{array}{l}\text { No Brasil, a prática } \\
\text { de sepultamentos } \\
\text { no interior das } \\
\text { igrejas e em seu } \\
\text { entorno foi trazida } \\
\text { pelos portugueses. }\end{array}$ & $\begin{array}{l}\text { Iniciou-se nas igrejas e } \\
\text { ao entorno da mesma. }\end{array}$ & $\begin{array}{l}\text { Existiam espaços } \\
\text { (necrópoles) } \\
\text { parados para } \\
\text { nobres e para a } \\
\text { plebe. }\end{array}$ & $\begin{array}{l}\text { Cemitérios paroquiais, ou } \\
\text { seja, dentro das próprias } \\
\text { igrejas eram construídos } \\
\text { para sepultamentos. } \\
\text { Os corpos eram enter- } \\
\text { rados no subsolo (piso } \\
\text { interior da igreja) ou em } \\
\text { sepulturas construídas na } \\
\text { superficie. } \\
\text { Em cemitério localizado } \\
\text { no rio de janeiro, os ca- } \\
\text { dáveres eram em grande } \\
\text { número e mal sepultados } \\
\text { numa grande vala comum, } \\
\text { quase exposto ao calor e } \\
\text { ao ar, liberando na atmos- } \\
\text { fera gases nauseabundo. } \\
\text { Na Bahia, a população } \\
\text { convivia com os mortos } \\
\text { lado a lado, nas ruas e } \\
\text { em frente à igreja, os pe- } \\
\text { destres andavam topando } \\
\text { com ossos, inclusive pe- } \\
\text { daços de crânios. } \\
\text { Em } 1828, \text { uma lei imperial } \\
\text { regulamentava a estru- } \\
\text { turara, funcionamento, } \\
\text { eleições, funções e outras } \\
\text { matérias referentes às câ- } \\
\text { maras municipais do Im- } \\
\text { pério do Brasil, a respeito } \\
\text { de cemitério ser estabele- } \\
\text { cidos fora do recinto dos } \\
\text { templos. } \\
\text { No século xIX, surgiram no } \\
\text { Brasil os cemitérios públi- } \\
\text { cos, a céu aberto, com tú- } \\
\text { mulos suntuosos no estilo } \\
\text { das necrópoles europeias. }\end{array}$ \\
\hline \multicolumn{7}{|c|}{$\begin{array}{l}\text { - Cemitérios no Brasil: Cemitério Santa Casa (1843); Campo Santo - Cemitério de Salvados (1836); Cemitérios dos Aflitos (século XVIII); Ce- } \\
\text { mitério Campo da Luz (1845); Cemitério da Consolação (1858); Cemitério do Araçá (1887); Cemitério do Brás (1893); Cemitério de Santana } \\
\text { (1897); Cemitério da Irmandade do Santíssimo Sacramento (1899); Cemitério Vila Mariana (1904). } \\
\text { - Na cidade de São Paulo, até } 2012 \text { eram contabilizados } 22 \text { cemitérios horizontais tracionais administrados pela prefeitura da cidade. } \\
\text { - Neles, em geral, são feitas inumações no solo (em cova rasa). } \\
\text { - Os particulares são 18, também horizontais e do tipo parque ou jardim. São áreas verdes, onde as inumações são feitas por entumula- } \\
\text { ção (jazigos subterrâneos). }\end{array}$} \\
\hline
\end{tabular}

Quadro 01. Escala temporal do surgimento das "formas cemiteriais" Fonte: elaborado a partir de PACHECO (2012). 
O surgimento das necrópoles partiu da necessidade de o homem enterrar seus mortos. Em todos os períodos da préhistória: Paleolítico, Mesolítico e Neolítico, a preocupação com o lugar adequado para enterrar os mortos foram surgindo conforme os problemas foram aparecendo por conta das interferências naturais das inumações nos espaços escolhidos para tal atividade (FARIA, 2008).

No início estes espaços foram determinados pela facilidade de se "livrar do corpo", não levando em conta qualquer preocupação com as consequências naturais provindas dos cadáveres. Com isso, as populações foram adequando-se conforme essas necessidades de saúde pública, a partir do momento que a população passou a sofrer com os cheiros nauseabundos provenientes das inumações, foram adaptando-se estratégias aos quais pudessem permanecer distantes destes espaços fétidos (SOUSA FILHO, 2015).

Conforme as mais diversas populações foram surgindo, observam-se os mesmos problemas e as soluções diferenciadas para resolver tais problemáticas. Os mortos para algumas civilizações havia um culto muito mais íntimo e valoroso, para outros era um corpo que precisaria ter um lugar para ser "despejado" (FARIAS, 2008).

As construções específicas de cada civilização surgiram a partir da localidade e de suas crenças, cada formato dos cemitérios possui uma cronologia de situações adversas provenientes principalmente de causas naturais causadas pelos cadáveres e suas inumações (PACHECO, 2012).

Os cemitérios estruturais surgiram justamente por causa de problemas naturais provindas da decomposição dos cadáveres, as populações foram repensando no lugar e na forma de enterrar por conta do incomodo proveniente do enterramento de seus mortos. E assim, houve um processo de mudanças e adaptações nessas construções das necrópoles até chegar ao modelo atual existente (SOUSA FILHO, 2015).

Lembrando que, esse processo deuse pelas situações exógenas (clima, solo, precipitação, sol, vento, além da fauna e flora) de cada lugar, onde trouxe adaptações nas construções das necrópoles, mas também as doenças aos quais atingiram populações onde levou a óbito inúmeras pessoas, fazendo com que levasse a civilização a preocuparse de como enterrar seu morto sem que ele seja afetado "diretamente" por ele (PACHECO, 2012).

\section{TERRITÓRIO E MOBILIDADE: ABORDAGEM COM ENFOQUE NAS NECRÓPOLES}

O espaço é anterior ao território. o território se forma a partir do espaço, é o resultado de uma ação conduzida por um ator. Ao se apropriar de um espaço, concreta ou abstratamente (pela representação), o ator "territorializa" o espaço. O território se apoia no espaço, mas não é o espaço. É uma produção, a partir do espaço (ITABORAHY, 2010).

O território, nessa perspectiva, é um espaço onde se projetou um trabalho, seja energia e informação, e que, por consequência revela relações marcadas pelo poder. A partir da territorialização do espaço é que se realizam as objetivações do espaço, que são processos sociais (RAFFESTIN, 1993).

O conceito de território traz uma contribuição na perspectiva do espaço definido e delimitado por e a partir de relações de poder. Para indicar este pressuposto na geografia política, se discute os muitos conceitos de território e os riscos de reducionismos entorno de um termo tão fundamental e tão polissêmico (SOUZA, 2012).

Souza (2012) amplia a sua discussão a partir da análise da prática social do cotidiano urbano, que delimita territórios para os mais 
diferentes objetivos, incorporando as noções e rede e a questão do desenvolvimento e seus desdobramentos na organização sócia espacial.

O território é fundamentalmente um espaço definido e delimitado por e a partir e relações de poder. A questão primordial, aqui, não é, na realidade, quais são as características geoecológicas e os recursos naturais de certa área, o que se produz ou quem produz em um dado espaço, ou ainda quais as ligações efetivas e de identidade entre um grupo social e seu espaço (ITABORAHY, 2010).

Estes aspectos podem ser de crucial importância para a compreensão da gênese de um território ou do interesse por tomá-lo ou mantê-lo, como exemplificam as palavras de SUN TZU - quem domina ou influencia e como domina ou influencia esse espaço? (SOUZA, 2012).

Com isso, as necrópoles também são territórios definidos e delimitados a partir da relação de poder existente neste espaço. As práticas sociais vivificadas foram desse ambiente a partir das ações antropogênicas da sociedade, também são estendidas aos espaços cemiteriais (RAMAZZINA, 2011).

A divisão de classe social, as condições econômicas das famílias, as crenças, ou seja, toda cultura individualizada do morto também faz parte deste território. As histórias dos mortos definem e estruturam a memória familiar, atestam ideologias políticas e indicam a divisão de classes. Apesar de um ambiente de "morte" os vivos são tão presentes quanto os mesmos, e as relações dos vivos com aqueles que "descasam" fazem parte dessa relação de poder (MUNDIM, 2011).

Territórios são construídos (e desconstruídos) dentro de escalas temporais as mais diferentes tais como: séculos, décadas, anos, meses ou dias; territórios podem ter um caráter permanente, mas também podem ter uma existência periódica, cíclica. Os limites do território não seriam, é bem verdade, imutáveis - pois as fronteiras podem ser alteradas, comumente pela força bruta -, mas cada espaço seria - enquanto território. Todo espaço definido e delimitado por e a partir de relações de poder é um território (SOUZA, 2012).

Os territórios mórbidos também constituem destes espaços construídos e (e desconstruídos) dentro das escalas temporais acima descritas, como se percebe no Quadro 01. Escala temporal do surgimento das "formas cemiteriais", o quanto estes territórios sofreram mudanças a partir das relações de poder exercidas conforme as civilizações, bem como a cultura, as crenças, o simbolismo e as religiões, assim como o surgimento e modelo de estruturação destes cemitérios (MUNDIM, 2011).

O território não diz respeito somente à materialidade do espaço, pois não há território exterior a relações sociais e este toma forma tanto por meio da inscrição no espaço físico, como nas narrativas, pois ele também é organizado discursivamente, quando se trata de territórios de povos para os quais a tradição oral ancorada na memória social tem peso importante, como os estudados por antropólogos (GODOI, 2014).

O território não é sinônimo de espaço ou espacialidade, ou como simplesmente "fonte de recursos" disputados ou, ainda, de elementar "apropriação da natureza". Territorialidade é "muitas vezes concebida em um sentido estrito como a dimensão simbólica do território" (HAESBAERT, 2004).

Dentro do simbolismo com os estudos antropológicos, as "cidades necrópoles" compõe esse território de construções abstratas como as tradições, os costumes, além de um espaço de memórias históricas, sociais, religiosas e culturais. Percebe-se que estes elementos fazem parte deste território e que não é possível desprendê-los pela relação direta aos quais permeiam os que lá fazem morada e também aqueles que cultuam os rituais fúnebres nestes espaços. Além dessa construção abstrata, o próprio 
formato (1. Cemitério-museu; 2. Cemitériojardim; 3. Lawn Reen Cemetery ou Cemitério Gramado; 4. Parkfridhof ou Cemitério-parque; e 5. Waldfriedhof ou Cemitério-floresta) dos cemitérios e os elementos que caracterizam estes territórios, também se constituem de uma arquitetura que é capaz de identificar o povo/civilização a partir do modelo utilizado (PACHECO, 2012).

A partir disso, vários enfoques são atribuídos ao conceito de território, um deles é o Atributo da territorialidade, é um termo plural, uma vez que se reporta a processos de construção de territórios, isto é, de apropriação, controle, usos e atribuição de significados (não necessariamente nessa ordem) sobre uma parcela do espaço que é transformada em território (GODOI, 2014).

A territorialidade ocorre com 0 sentimento forte de pertencimento a um lugar e a uma rede de parentes. Território Simbólico, com os processos de desterritorialização são múltiplos e nada recentes (GODOI, 2014).

O território usado envolve todos os atores e todos os aspectos e, por isso, é sinônimo de espaço banal, corriqueiro, espaço de todas as existências. A história se produz com todas as empresas, todas as instituições, todos os indivíduos, independentemente de sua força diferente, apesar de sua força desigual. Neste sentido, os cemitérios são espaços que envolvem os atores "mortos" e também os vivos nestes processos de vivificações (SANTOS, 1996).

Relatar a história do território é operacionalizar as técnicas que explicam cada período, é reconstruir o transcurso que leva do meio natural ao meio técnico e ao meio técnico-científico-informacional. Os processos históricos dos cemitériostambém é uma forma de conhecer cada civilização, as sepulturas são testemunhas não só a erupção da morte na vida humana, mas também modificações antropológicas que permitem e provocaram essa erupção (SILVEIRA, 2011; MORIN, 1970).

O território usado abriga as ações passadas, já cristalizadas nos objetos e normas, e as ações presentes, que estão se realizando diante dos nossos olhos. As ações passadas - os lugares são vistos como coisas. Mas a combinação das ações presentes e ações passadas fazem o viver, traz vida, por isso, uma não pode ser entendida sem a outra e é por isso que o espaço é sempre histórico. Sua historicidade deriva da junção entre as características da materialidade territorial e as características das ações presente denominando-se território vivo, o território vivendo. É o território no processo de ser usado (SILVEIRA, 2011).

Nada como reviver estes espaços usados a partir do território dos mortos, os cemitérios são objetos que combinam ações passadas, bem como ações do presente e que servem para melhorar as ações futuras. No processo históricodos cemitérios percebese que os atores que perpassaram nas mais diversas escalas temporais civilizatórias foram de fundamental importância para atrair diferentes olhares para as necrópoles de forma que melhorassem estes lugares ao longo de suas necessidades (MUNDIM, 2011).

As populações foram adequando-se conforme as necessidades de saúde pública. A partir do momento que a população passou a sofrer com os cheiros nauseabundos provenientes das inumações, foram adaptando-se estratégias aos quais pudessem permanecer distantes destes espaços fétidos (RAMAZZINA, 2011).

Dentro do território, a mobilidade se caracteriza pela interação entre diversas variáveis, sendo as básicas o espaço (trajeto, itinerário ou percurso), a velocidade e o tempo. A relação entre estas variáveis imprimem, ao objeto móvel, condições de inércia ou de deslocamento. Os cemitérios permeiam nessa relação inerte e de mobilidade tanto de objetos, quanto dos cadáveres, e dos vivos que cultuam os mortos (LEMOS, 2007).

A mobilidade permeiam as inúmeras dimensões (religião, ideologia, nacionalidade, 
status econômico, cultura, raça, sexo, idade) e a mobilidade por entre elas pode ocorrer de forma vertical (um grupo em relação a outro) ou horizontal (dentro de um mesmo grupo), nos cemitérios essas dimensões são claras e existentes tanto para os que estão mortos quanto para os vivos (LEMOS, 2009).

A cidade é lugar de contenção e de atração (MUMFORD, 1988). Acidade se realiza nos fluxos de mobilização, mistura e ampliação que se opõem ao isolamento e à autonomia mais fechada das antigas aldeias. As cidades contemporâneas são lugares de circulação e de dispersão, de exterioridades, privacidade e indiferença, um lugar de "inquietude" e turbulência. As cidades necrópoles são lugares indiferentes aos olhares dos vivos a partir da própria conduta ao tratar o morto, a perturbação do local exterioriza a não preocupação do homem, trazendo a indiferença com o cuidado para com este espaço(CAIAFA, 2007).

\section{CONSIDERAÇÕES FINAIS}

As necrópoles não são apenas territórios simbólicos, são espaços que constituem funcionalidades do passado e que trazem especificidades para o presente. O futuro destes espaços ainda não se sabe, apesar das mudanças históricas, de infraestrutura e de saúde pública ao longo das civilizações.

Oscemitérios ainda possuem comportamentos históricos e que permeiam no século atual, bem como os rituais fúnebres, o uso dos elementossimbólicos, as crenças, a religiosidade, das estruturasarquitetônicas entre outros. Ademais, em outros aspectos importantes para a sociedade necessitam de um enfoque maior, tais como as problemáticas de saúde pública e ambiental. Portanto, os mortos ainda trazem transtornos e preocupações aos vivos.

As cidades necrópoles são territórios sociais, culturais, simbólicos, religiosos, econômicos, naturais, arquitetônicos, de saúde pública e demais características que compõe este espaço e identifica suas civilizações ao longo dos tempos. É um território que possui fluxos de mobilidades fisicas e abstratas.

São inúmeras mobilidades existentes nestes espaços, e não se fecham apenas neste território delimitado, mas, vão além destes muros, as pessoas que circulam nestes ambientes fazem parte desta mobilidade física, bem como a mobilidade dos mortos em suas fases de mudanças temporais a partir do estágio de putrefação do corpo. Além destas transitações físicas, as abstratas estão presentes, como já foram citadas por Lemos. $\mathrm{E}$ não cabe apenas para os mortos, mas também para os vivos.

\section{REFERÊNCIAS}

CAIAFA, J. A Aventura das Cidades: ensaios e etnografias. Rio de Janeiro: FGV, 2007.

COSTA, B. F. Instituto de Ciências Humanas Programa de Pós-Graduação em Memória Social e Patrimônio Cultural. 2015. Tese de Doutorado. UNIVERSIDADE FEDERAL DE PELOTAS.

CURY, I. Organizadoras Cartas Patrimoniais. 2. ed. IPHAN, Rio de Janeiro, 2000.

FARIA, A. F. Engajamento de estudantes em atividade de investigação. Universidade Federal de Minas Gerais. Recuperado de http:/ / dspace. Icc. ufmg. br/dspace/bitstream/1843/ FAEC-84XHTF/1/dissertacao_faria_a_f. pdf, 2008.

GODOI, E. P. de. Territorialidade: trajetória e usos do conceito. Revista Raizes. v. 34, n. 2, p. 8-16, jul./dez. 2014. Disponível em: <http:// www.ufcg.edu.br/ raizes/artigos/Artigo_339. pdf>. Acesso em: 21 de jun. de 2016.

HAESBAERT, R. 0 Mito da Desterritorialização: do "fim dos territórios" à multiterritorialidade. 
Rio de Janeiro: Beltrand Brasil, 2004.

ITABORAHY, N. Z. A Geografia, o Conceito do Território e os processos de territorialização das Comunidades Quilombolas: Primeiras Aproximações. Anais XVI Encontro Nacional dos Geógrafos. Crise, práxis e autonomia: espaços de resistência e de esperanças. Espaço de Diálogos e Práticas, p. 25-31, 2010.

KEMERICH, P. D. da Cunha. et al. A questão ambiental envolvendo os cemitérios no Brasil. Revista Monografias Ambientais, v. 13, n. 4, p. 3777-3785, 2014.

KOURY, M. G. P. O luto no Brasil no final do século XX. Caderno CRH, v. 27, n. 72, p. 593-612, 2014.

LEMOS, A. Cidade e Mobilidade: telefones celulares, funções pós-massivas e territórios informacionais Matrizes. 2007. ISSN 19822073. Disponível em: <http:/ / www.redalyc.org/ articulo.oa?id=143017362007>. Acesso em: 23 de fev. de 2017.

LEMOS, A. Cultura da mobilidade. Revista Famecos. Porto Alegre, n. 40, p. 28-35, dez. 2009. Disponivel em: <http://revistaseletronicas. pucrs.br/ojs/index.php/revistafamecos/ article/view/6314/4589>. Acesso em: 23 de fev. de 2017.

LEON LUCAS, A. Os Cemitérios no Bairro Fragata: uma relação entre 0 antigo e 0 contemporâneo. Monografia. Pós-Graduação em Artes: Especialização em Patrimônio. Instituto de Artes e Design. Universidade Federal de Pelotas. Pelotas, 2006, p. 105.

MARTINS, F. G. Arquitetura funerária: conceitos e lógicas propositivas no cemitério do século XX. 2015. Dissertação de Mestrado.

MORIN, E. 0 homem Perante a Morte. Lisboa: publicações Europa-América, 1970.
MUMFORD, L. A Cidade na história. São Paulo: Martins fontes, 1991.

MUMFORD, L. A Cidade na História: suas origens, transformações e perspectivas. São Paulo: Martins Fontes, 1988.

MUNDIM, L. G. M. As necrópoles como patrimônio cultural: Reflexões sobre 0 inventário do Cemitério do Bonfim em Belo Horizonte. Anais do XXVI Simpósio Nacional de História-ANPUH. São Paulo, 2011.

NEGRAES, E de C. O Livro dos Mortos do Antigo Egito. ed. Hemus. Tradução de 1982.

PACHECO, A. Meio Ambiente e Cemitérios. São Paulo: Editora SENAC São Paulo, 2012.

PALMA, S. R. A saudade ecologicamente correta: a educação ambiental e os problemas ambientais em cemitérios. 2010.

PINHEIRO, T. M. de. Contaminação ambiental causada pelo necrochorume proveniente de cemitérios.INOVAE - ISSN: 2357-7797, São Paulo, v. 6, JAN-DEZ, 2018 - pág. 145-171.

RAfFestin, C. Por uma Geografia do Poder. Tradução Maria Cecília França. São Paulo: Ática, 1993. (Série Temas, 29).

RAMAZZINA, A. A. Estrutura social e organização espacial de necrópoles: aspectos teóricometodológicos no estudo arqueológico de vestígios funerários-Uma revisão bibliográfica. In: Revista do Museu de Arqueologia e Etnologia, Trabalhos apresentados no XVII Congresso Nacional de Estudos Clássicos, Natal, São Paulo. 2011. p. 81-109.

RANGONI, C. S. Cemitério Municipal de São Francisco: visão crítica sobre as condições das necrópoles de Salvador. CANDOMBÁ - ISSN 1809-0362, v. 10 | N. 1 | JAN - dez 2014.

SANTOS, M. A Natureza do Espaço. São Paulo: 
Hucitec, 1996.

SILVEIRA, M. L. O Brasil: território e sociedade no início do século 21: a história de um livro. Acta Geográfica. Edição Especial. Cidades na Amazônia Brasileira, 2011. p. 151-163. Disponível em: <http://revista.ufrr.br/index. php/actageo/article/view/556>. Acesso em: 22 de mar. de 2017.

SOUSA FILHO, A. F. de. Necrópole vertical: uma alternativa sustentável para Belo Horizonte / Antenor Ferreira de Sousa Filho. - Belo Horizonte, 2015. $155 \mathrm{f}$.

SOUZA VAZ, F. Memória Sobre a Inconveniência dos Enterros nas Igrejas e Utilidade da construção de Cemitérios. Porto, 1835.

SOUZA, M. J. L. de. O Território: sobre espaço e poder, autonomia e desenvolvimento. 2012. In: CASTRO, I. E. de.; GOMES, P. C. da C.; CORRÊA, R. L. Geografia: conceitos e temas. 15. ed. Rio de Janeiro: Bertrand Brasil, 2012.

TELLES, L. S. Manual do Patrimônio Histórico. Universidade de Caxias do Sul: 1977. 